\title{
Policy Uncertainty, Economic Activity And Carbon Emissions: A Nonlinear Autoregressive Distributed Lag Approach
}

Malihe Ashena ( $\nabla$ ashena@buqaen.ac.ir)

Bozorgmehr University of Qaenat

\section{Ghazal Shahpari}

Tarbiat Modares University

\section{Research Article}

Keywords: $\mathrm{CO} 2$ emissions, Economic policy uncertainty, Economic growth, NARDL approach, Uncertainty Index.

Posted Date: December 1st, 2021

DOI: https://doi.org/10.21203/rs.3.rs-933153/v1

License: (1) This work is licensed under a Creative Commons Attribution 4.0 International License.

Read Full License

Version of Record: A version of this preprint was published at Environmental Science and Pollution Research on March 8th, 2022. See the published version at https://doi.org/10.1007/s11356-022-19432-3. 


\title{
Policy uncertainty, economic activity and carbon emissions:
} A nonlinear autoregressive distributed lag approach

\author{
Malihe Ashena ${ }^{1}$ \\ Assistant prof. of Economics, Bozorgmehr University of Qaenat, Qaen, Iran \\ Ghazal Shahpari ${ }^{2}$ \\ Ph.D of Economics, Tarbiat Modares University, Tehran, Iran
}

\section{Acknowledgment}

This article is taken from a research project entitled "Investigation of the asymmetric effect of economic policy uncertainty on pollution emissions using the NARDL approach" approved by the Research Council of Bozorgmehr University of Qaenat, notification number 39215.

The authors would like to thank Bozorgmehr University of Qaenat for the financial support of this research. 6

7

8

9

0

1

2

3

4

5

6

7

8

\footnotetext{
1 Corresponding author. Email: ashena@buqaen.ac.ir. Fax: 05631006009

2 Email: g.shahpari@modares.ac.ir
} 
Policy uncertainty, economic activity and carbon emissions:

A nonlinear autoregressive distributed lag approach

Abstract

Over the last few years, economic uncertainty has become a global concern. Not only has its impact on economic activities, but there are pieces of evidence that show uncertainty can be the reason for $\mathrm{CO}_{2}$ emissions. It is also expected that the economic policy uncertainty may decrease or delay economic production, which may lead to a reduction in carbon emissions. Furthermore, uncertainty may decrease friendly environment policies and budgets, which cause increase in carbon emissions. Thus, there may be an asymmetric relationship between economic uncertainty and the amount of $\mathrm{CO}_{2}$ emissions. This study investigates the effects of economic policy uncertainty and economic activity on carbon emission applying a Nonlinear Autoregressive Distributive Lag (NARDL) cointegration approach in Iran between 1971 and 2018. Findings show that both policy uncertainty and economic growth contribute to $\mathrm{CO}_{2}$ emissions. The negative and positive shocks of GDP and uncertainty index on $\mathrm{CO}_{2}$ emissions in both the short-run and long-run are significant. It can be concluded that there is an asymmetric effect of economic production on $\mathrm{CO}_{2}$ emissions in Iran. The results of analyzing asymmetric effects of economic uncertainty show a symmetric relationship between uncertainty index and $\mathrm{CO}_{2}$ emissions. In a way that a shock in uncertainty index lowers carbon emission. To sum up, since uncertainty may affect the analysis of carbon emissions incorrectly, some environmental policies such as allocating a budget for R\&D on clean energy, and environmental taxes must be implemented.

Keywords $\mathrm{CO}_{2}$ emissions . Economic policy uncertainty . Economic growth . NARDL approach . Uncertainty Index.

\section{Introduction}

Climate change, global warming, and environmental problems are the most critical issues in the recent decade (Anser et al. 2020). These factors can easily lead to a rise in aerosols and air pollution (Anser et al. 2021.a). Air pollution can also have noticeable side effects on the national economy (Chang et al. 2020). Since climate change and environmental degradation can result in several human diseases (Shahpari et al. 2021), they attracted the attention of international agencies to mitigate Greenhouse Gas (GHG). Furthermore, the GHG level is the main reason for global warming. Carbon dioxide $\left(\mathrm{CO}_{2}\right)$ as a primary greenhouse gas consists around $80 \%$ of $\mathrm{GHG}$ emissions, which is emitted trough human activities (IPCC, 2013). Therefore, limiting and controlling carbon dioxide emissions can reduce the adverse effects of climate change (Kompas et al. 2018; Atsu and Adams 2020). Climate change is an important challenge that may threaten attaining sustainable development through economic and environmental aspects. Therefore, to achieve sustainable development, a decrease in $\mathrm{CO}_{2}$ emission is a critical fact. The process of how

66 GHG emissions can impact the environment and the importance of $\mathrm{CO}_{2}$ emissions are illustrated in Fig. 1. 


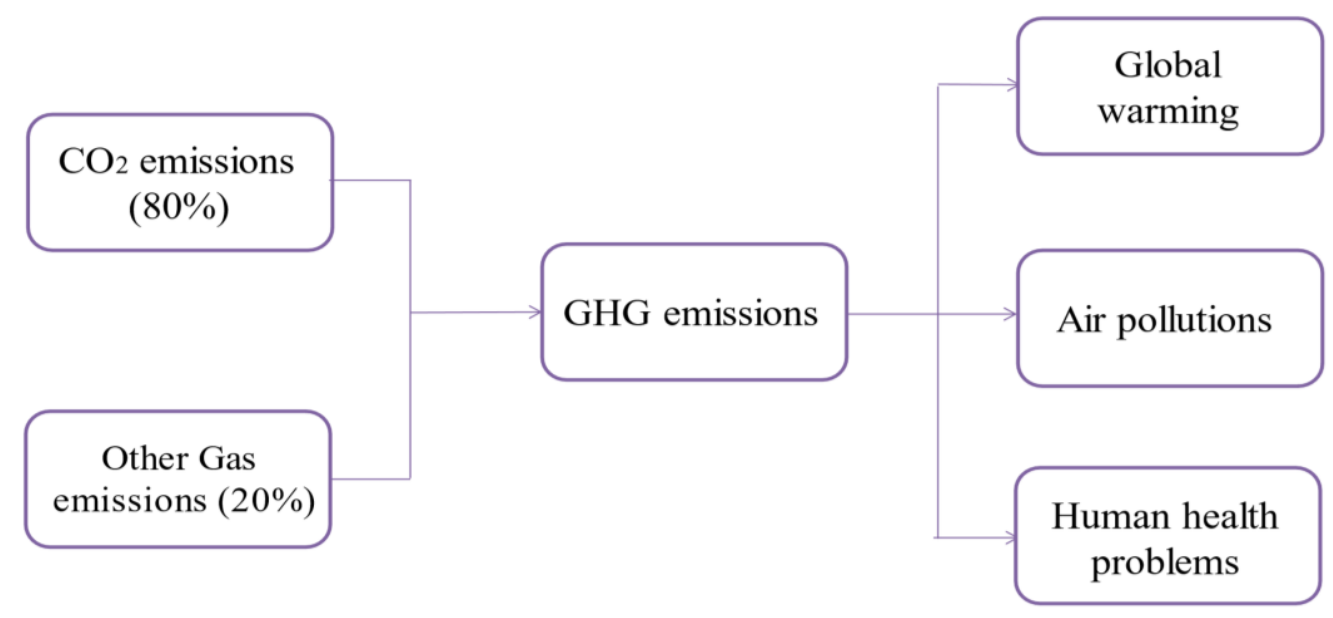

Fig. 1. The importance of $\mathrm{CO}_{2}$ emissions

Simultaneously, concerns about Economic Policy Uncertainty (EPU) are another global concern. There are several literatures studying the effects of uncertainty on GDP or economic growth (Baker et al. 2016; Barrero et al. 2017; Wang and Sun 2017; Sahinoz and Erdogan Cosar 2018; Ghosh 2019; Altig et al. 2020; Alam and Istiak 2020; Razmi et al. 2020; Adedoyin and Zakari 2020; Anser et al. 2021.b). However, the critical point about economic uncertainty is that besides its economic consequences, it also has some environmental impacts implicitly (Atsu and Adams 2021; Reza Syed and Bouri 2021).

It is expected that policy uncertainty increases the cost of production. Uncertainty can easily encourage firms to compensate modern technology with an unfriendly environment and old production lines to decrease their cost of production. This change undoubtedly leads to an increase in the amount of $\mathrm{CO}_{2}$ emissions. In addition, the budget allocated to renewable energy's R\&D and innovation methods may reduce in uncertain circumstances. This could also result in a rise in fossil fuel consumption, leading to increased $\mathrm{CO}_{2}$ emissions. Adams et al. (2020) stated that economic policy uncertainty might increase $\mathrm{CO}_{2}$ emissions, especially in resource-rich countries, because policy uncertainty may limit innovations to reduce energy consumption and carbon emissions. On the other hand, policy uncertainty may decrease or delay economic production, which in turn will cause a reduction in carbon emissions (Chen et al. 2021).

Economic uncertainty is a helpful index to forecast a recession because as the uncertainty increase, firms decrease or delay their consumption and investment (Ercolani and Natoli 2020; Adedoyin and Zakari 2020). Therefore, it can be concluded that economic uncertainty will affects the investment plans.

Based on the above description of how uncertainty may have a relationship with the amount of $\mathrm{CO}_{2}$ emissions, it can be concluded that economic uncertainty can either lead to a decrease or even an increase in $\mathrm{CO}_{2}$ emissions. In other words, there can be an asymmetric relationship between economic uncertainty and the amount of $\mathrm{CO}_{2}$ emissions. These consequences have been summarized in Fig. 2. 


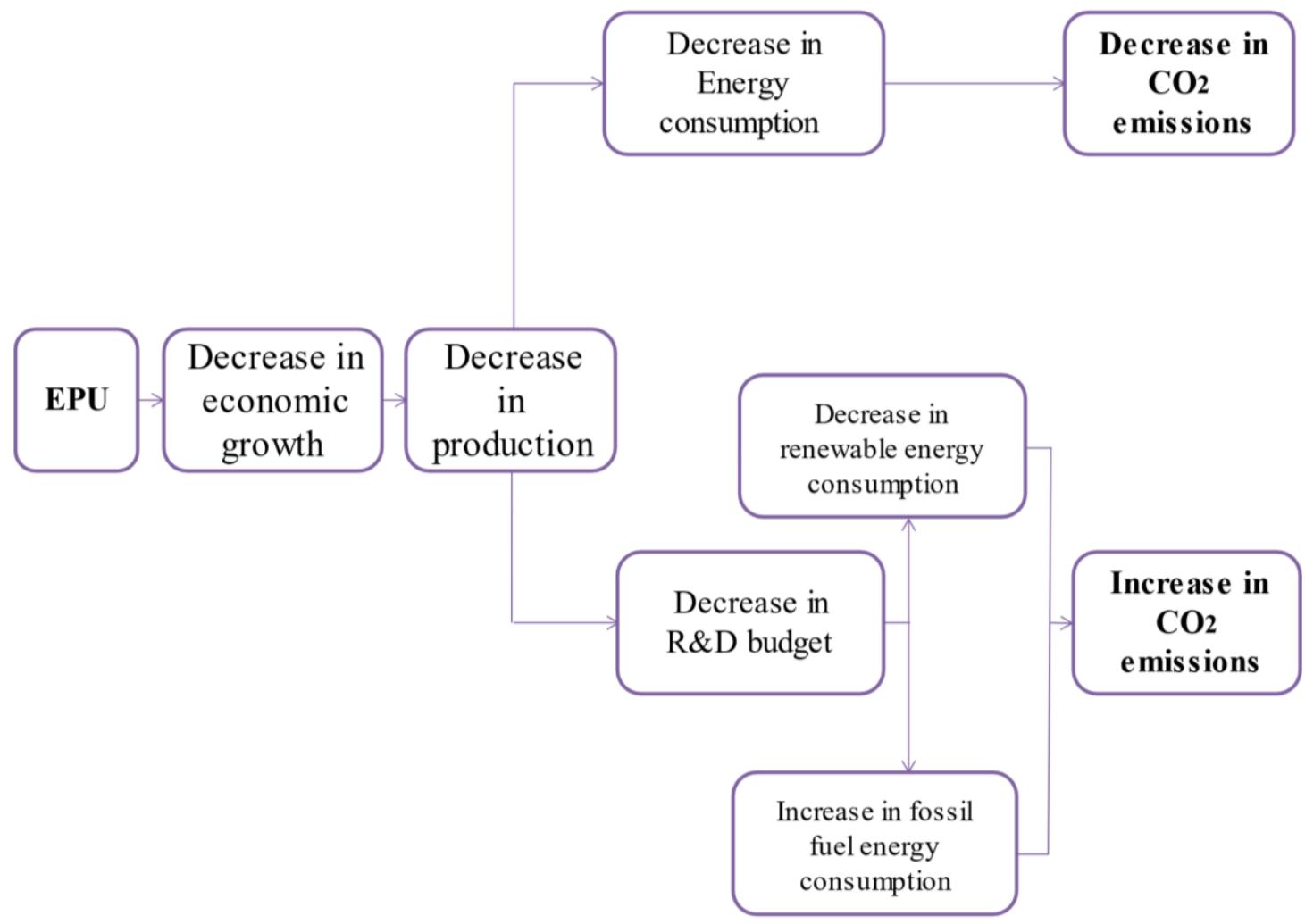

Fig. 2. The asymmetric effect of economic uncertainty on the amount of $\mathrm{CO}_{2}$ emissions

Thus, studying policy uncertainty is essential to evaluate environmental effects and to provide policymakers with more robust information for reducing $\mathrm{CO}_{2}$ emissions. This study tries to add new insights to the existing studies by exploring an index that incorporates the uncertainty condition of economics, which affects carbon emissions via economic activity changes. Specifically, the current research applies the asymmetric approach of the ARDL model to determine the effects of uncertainty index and GDP on $\mathrm{CO}_{2}$ emissions.

Economic growth is the most significant phenomenon that can lead to environmental pollution and $\mathrm{CO}_{2}$ emissions. In fact, in the initial steps of economic growth, countries pay more attention to production and less attention to environmental issues. The production methods and processes are not high-tech and efficient enough to prevent environmental problems (Dinda 2004; Pata et al. 2018). During economic growth time, the increase in the use of natural resources is inevitable. Indeed, during these years, natural resources consumption will be more than production capacity. Therefore, the amount of GHG emissions would be at higher levels (Pata et al. 2018). Increasing GHG emissions is a worldwide issue whose effect is not limited to a specific part of the world. This issue needs tackling instantly and globally (Hosseini et al. 2019).

According to the above discussion, developing countries choose higher production levels to achieve higher levels of economic growth, considering environmental pollution. According to the inverted U-shaped of Kuznets curve, the relationship between economic growth and environmental pollution depends on the development levels. When a developing country faces an increase in income per capita and welfare, economic growth and environmental pollution will negatively 
affect it. Thus, there would be a change in the relationship between economic growth and environmental degradation at the developed stages. Finally, as the development process continues, countries start to improve their production technologies, and the environmental degradation reduces (Stern 2004).

Iran is a developing country and one of the top 10 countries of $\mathrm{CO}_{2}$ emitters (Ashena et al. 2020). Iran has been faced with different kinds of economic sanctions, providing economic uncertainty in recent decades. Therefore, it is an important issue to study how the economy reacts aftermath of such shocks. To the best of our knowledge, this is the first study that considers the impacts of uncertainty on $\mathrm{CO}_{2}$ emissions in Iran. Furthermore, this study employs a nonlinear ARDL approach, which yields reliable results as it incorporates asymmetric effects. This study differs from previous papers in terms of the type of indicators, time series of a single country, and the method.

The rest of this article is organized as follows. In section 2, the background of study and study area has been expanded. Section 3 explains the methodology. Data and results are provided in section 4 , while this article is concluded in section 5.

\section{Literature Review}

\subsection{Previous Studies}

Some studies show that economic growth is directly related to the increase in $\mathrm{CO}_{2}$ emissions (Apergis and Payne 2010; Nejat et al. 2015; Xu et al. 2018). Other studies such as Shahbaz et al. (2020) determined the validity of the EKC hypothesis, indicating that economic growth can produce solutions to environmental problems in the long run. To sum up, most empirical assessment of the nexus between carbon emissions and GDP shows mixed outcomes.

Table 1 summarizes studies about the relationship between $\mathrm{CO}_{2}$ emissions, economic growth, and EPU.

Table 1 Lists of previous studies

\begin{tabular}{|c|c|c|c|}
\hline Authors & Findings & Methodology & $\begin{array}{l}\text { Region of } \\
\text { study }\end{array}$ \\
\hline $\begin{array}{l}\text { Shafiullah et } \\
\text { al. (2021) }\end{array}$ & $\begin{array}{l}\text { Using data from } 1986 \text { to } 2019 \text {, they tried to } \\
\text { model the consequences of economic policy } \\
\text { uncertainty on renewable energy consumption. } \\
\text { They showed that there is a negative long-run } \\
\text { relationship between EPU and renewable energy } \\
\text { consumption. }\end{array}$ & $\begin{array}{l}\text { Nonlinear } \\
\text { economic } \\
\text { approaches }\end{array}$ & USA \\
\hline $\begin{array}{l}\text { Atsu and } \\
\text { Adams } \\
(2021)\end{array}$ & $\begin{array}{l}\text { Throughout 1984-2017, they found fossil fuel } \\
\text { consumption and EPU stirring up } \mathrm{CO}_{2} \text { emissions. } \\
\text { However, renewable energy along with financial } \\
\text { development mitigate } \mathrm{CO}_{2} \text { emissions. Therefore, } \\
\text { they suggested promoting an economic policy to }\end{array}$ & $\begin{array}{l}\text { Cross-sectional } \\
\text { augmented } \\
\text { ARDL model }\end{array}$ & $\begin{array}{l}\text { Five } \\
\text { selected } \\
\text { countries }\end{array}$ \\
\hline
\end{tabular}




\begin{tabular}{|c|c|c|c|}
\hline & $\begin{array}{l}\text { stimulate investment in energy efficiency } \\
\text { technology to reduce } \mathrm{CO}_{2} \text { emissions. }\end{array}$ & & \\
\hline $\begin{array}{l}\text { Sohail et al. } \\
(2021)\end{array}$ & $\begin{array}{l}\text { They found that monetary policy uncertainty can } \\
\text { negatively affect renewable energy consumption } \\
\text { in the short run and long run. }\end{array}$ & ARDL model & USA \\
\hline $\begin{array}{l}\text { Reza Syed } \\
\text { and Bouri } \\
(2021)\end{array}$ & $\begin{array}{l}\text { They find that in the short run, EPU intensifies } \\
\mathrm{CO}_{2} \text { emissions. However, in the long run, EPU } \\
\text { decreases } \mathrm{CO}_{2} \text { emissions, and therefore, higher } \\
\text { levels of EPU can improve environmental } \\
\text { quality. }\end{array}$ & $\begin{array}{l}\text { A bootstrap } \\
\text { ARDL } \\
\text { approach }\end{array}$ & USA \\
\hline $\begin{array}{l}\text { Zakari et al. } \\
(2021)\end{array}$ & $\begin{array}{l}\text { From } 1985 \text { to } 2017 \text {, they found a positive } \\
\text { relationship between energy consumption and } \\
\text { EPU with } \mathrm{CO}_{2} \text { emissions. However, this study } \\
\text { also showed a negative relationship between } \\
\text { renewable energy and } \mathrm{CO} 2 \text { emissions in the long } \\
\text { run. }\end{array}$ & $\begin{array}{l}\text { Pooled Mean } \\
\text { Group } \\
\text { (PMG) ARDL } \\
\text { approach }\end{array}$ & $\begin{array}{l}\text { OECD } \\
\text { countries }\end{array}$ \\
\hline $\begin{array}{l}\text { Anser et al. } \\
(2021 . a)\end{array}$ & $\begin{array}{l}\text { They studied the WUI on } \mathrm{CO}_{2} \text { emissions. For } \\
\text { 1990-2015, they showed that an increase in WUI } \\
\text { could decrease } \mathrm{CO}_{2} \text { emissions both in the short } \\
\text { and long run. }\end{array}$ & $\begin{array}{l}\text { a PMG-ARDL } \\
\text { approach }\end{array}$ & $\begin{array}{l}\text { Top ten } \\
\text { carbon } \\
\text { emitter } \\
\text { countries }\end{array}$ \\
\hline $\begin{array}{l}\text { Anser et al. } \\
(2021 . b)\end{array}$ & $\begin{array}{l}\text { They showed that EPU and non-renewable } \\
\text { energy consumption could lead to environmental } \\
\text { degradation. However, on the other hand, } \\
\text { renewable energy consumption can result in a } \\
\text { better ecological situation. }\end{array}$ & $\begin{array}{l}\text { OLS and } \\
\text { Dynamic } \\
\text { Regression }\end{array}$ & $\begin{array}{l}\text { Selected } \\
\text { emerging } \\
\text { economic } \\
\text { s }\end{array}$ \\
\hline $\begin{array}{l}\text { Razmi et al. } \\
(2020)\end{array}$ & $\begin{array}{l}\text { Their findings showed that EPU could play a } \\
\text { vital role in forcing investors to transfer their } \\
\text { investment to other sectors of the economy with } \\
\text { more stability from } 2009 \text { to } 2017 \text {. }\end{array}$ & $\begin{array}{l}\text { GARCH- } \\
\text { MIDAS } \\
\text { approach }\end{array}$ & Iran \\
\hline $\begin{array}{l}\text { Pirgaip and } \\
\text { Dincergok } \\
(2020)\end{array}$ & $\begin{array}{l}\text { From } 1998 \text { to } 2018 \text {, they showed unidirectional } \\
\text { causality from EPU to energy consumption in } \\
\text { Japan. However, the same causality was found } \\
\text { from EPU to } \mathrm{CO}_{2} \text { emissions in the USA and } \\
\text { Germany. On the other hand, Canada has a } \\
\text { unidirectional causality from EPU to } \mathrm{CO}_{2} \\
\text { emissions and energy consumption. }\end{array}$ & $\begin{array}{l}\text { A bootstrap } \\
\text { panel, Grenger } \\
\text { causality test }\end{array}$ & $\begin{array}{l}\text { G7 } \\
\text { countries }\end{array}$ \\
\hline $\begin{array}{l}\text { Adedoyin } \\
\text { and Zakari } \\
(2020)\end{array}$ & $\begin{array}{l}\text { Based on their study on annual data from } 1985- \\
2017 \text {, EPU is more important in the short run and } \\
\text { can increase } \mathrm{CO}_{2} \text { emissions. Nevertheless, on the } \\
\text { other hand, in the long run, EPU reduces } \mathrm{CO}_{2} \\
\text { emissions. The Granger causality showed that } \\
\text { there is a one-way causality between: } \\
\text { Energy consumption and } \mathrm{CO}_{2} \text { emission, } \\
\mathrm{CO}_{2} \text { emission and EPU, } \\
\text { Energy consumption and EPU. }\end{array}$ & ARDL model & UK \\
\hline
\end{tabular}




\begin{tabular}{|l|l|l|l|}
\hline $\begin{array}{l}\text { Wang et al. } \\
(2020)\end{array}$ & $\begin{array}{l}\text { From } 1960 \text { to 2016, they showed that per capita } \\
\text { income increases } \mathrm{CO}_{2} \text { emissions in the long run. } \\
\text { They used WUI as a proxy for EPU. Based on } \\
\text { their findings, in the long run, WUI increases } \\
\mathrm{CO}_{2} \text { emissions. }\end{array}$ & ARDL model \\
\hline $\begin{array}{l}\text { Adams et al. } \\
(2020)\end{array}$ & $\begin{array}{l}\text { From } 1996 \text { to } 2017, \text { they find that in the short run, } \\
\text { EPU intensifies } \mathrm{CO}_{2} \text { emissions. However, in the } \\
\text { long run, EPU decreases CO emissions, and } \\
\text { therefore, higher levels of EPU can improve } \\
\text { environmental quality. } \\
\text { To study countries with high geopolitical risk, } \\
\text { their results showed that in the long run; there is } \\
\text { a significant relationship between economic } \\
\text { uncertainty and } \mathrm{CO}_{2} \text { emissions. }\end{array}$ & $\begin{array}{l}\text { A group } \\
\text { of high } \\
\text { geopolitic } \\
\text { al } \\
\text { countries }\end{array}$ \\
\hline $\begin{array}{l}\text { Yu et al. } \\
(2020)\end{array}$ & $\begin{array}{l}\text { They estimated the effects of EPU on } \\
\text { manufacturing firms } \mathrm{CO} \text { emissions. They } \\
\text { showed that an increase in EPU could increase } \\
\text { carbon emission intensity for firms. They even } \\
\text { concluded that firms try to use cheap and dirty } \\
\text { fossil fuels to respond to this rising by an increase } \\
\text { in uncertainty. }\end{array}$ & $\begin{array}{l}\text { An unbalanced } \\
\text { panel data }\end{array}$ & China \\
\hline
\end{tabular}

144

\section{2}

3

\subsection{Theoretical background}

In the 2015 United Nations Climate Change Conference in Paris, Iran made an international commitment in order to reduce $\mathrm{CO}_{2}$ emissions. According to this commitment, Iran has to reduce $8-12 \%$ of the $\mathrm{CO}_{2}$ emissions from its level in 2005 by 2030 as its long-run development plan (Hosseini et al. 2019; Ashena et al. 2020). In Fig. 3, the Iran $\mathrm{CO}_{2}$ emissions rate of growth from 2001 to 2019 has been illustrated. From Fig. 3, it is evident that during this time interval, the rate of growth is always positive except for 2015, when the commitment was signed.

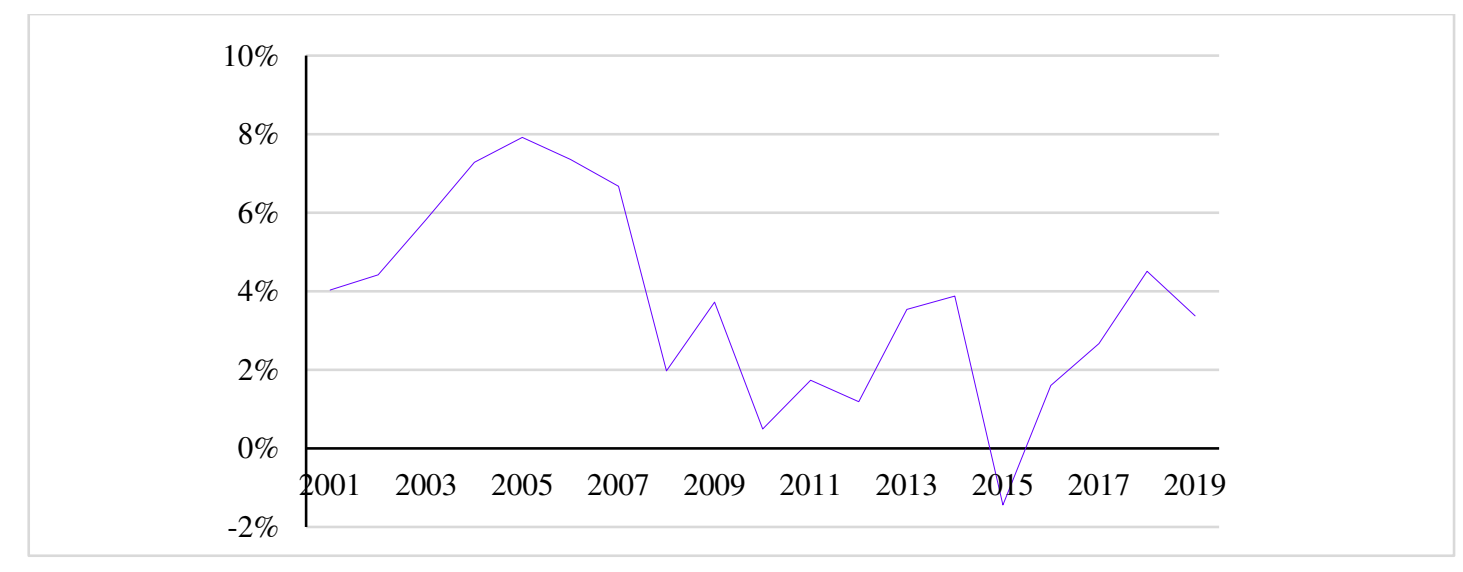

Fig. 3. $\mathrm{CO}_{2}$ emissions rate of growth from 2001 to 2019 in Iran 
There is not a single definition for economic uncertainty, according to the literature. In other words, there is no agreed-upon unique definition for the concept of economic uncertainty (Al-Thaqeb and Algharabali 2019). However, Jin and Wu (2021) explained EPU as the uncertainty associated with signs in monetary and fiscal policies and government regulations that influence how people and firms have their economic activities. In general, economic uncertainty can be categorized into different groups:

1. Uncertainty contributes to market volatility such as regulatory or monetary policies

2. Unexpected changes contribute to the economic ecosystems (Al-Thaqeb and Algharabali 2019).

The other important point is that many factors can be the reason for uncertainty. Moreover, some of these factors have both short-run and long-run effects. Therefore, to study the effects of economic uncertainty, it is essential to consider the time horizon.

There are some indices to measure uncertainty; for instance, the Chicago Board Options Exchange has been used the volatility index (VIX) for many years as an accepted proxy for firm uncertainties in the equity market (Al-Thaqeb and Algharabali 2019). However, VIX works best for mature markets and is not appropriate for all countries. Methods of text-mining and word counting are usual ways to measure economic uncertainty: keyword-based methods. Regarding these methods, some keywords identify the index, such as "uncertain" and "uncertainty." Thus, uncertainty index is measured by news containing these keywords (Al-Thaqeb and Algharabali 2019; Kaveh-Yazdy and Zarifzadeh 2021). Economic Policy uncertainty (EPU) is an uncertainty index calculated based on text-mining in newspaper articles of leading newspapers. World Uncertainty Index (WUI) is another measure of uncertainty, which uses a single source for all countries to compare the level of uncertainty across countries. This index captures uncertainty related to economic and political events.

Fig. 4. shows the time trend of the carbon emissions, GDP, and economic uncertainty for Iran during the research period. As it is shown, GDP and $\mathrm{CO}_{2}$ variables have been increasing, while economic uncertainty fluctuates during the research period. Meanwhile, WUI has been experiencing a positive upward trend since 2011.

WUI

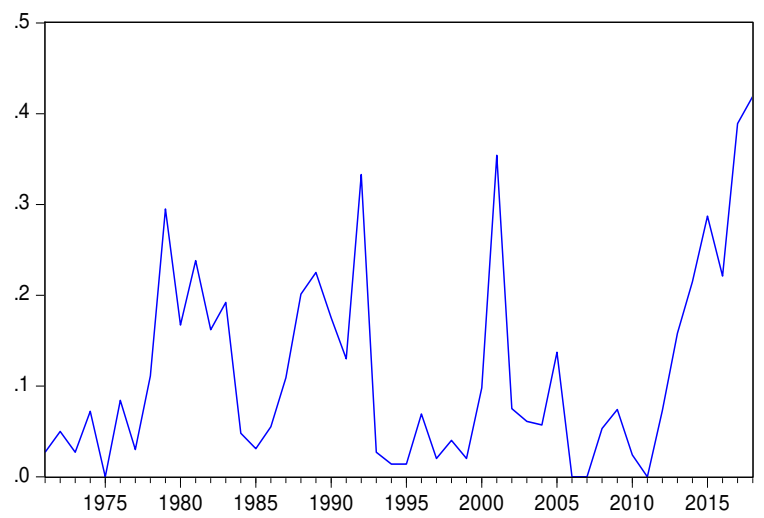

LCO2

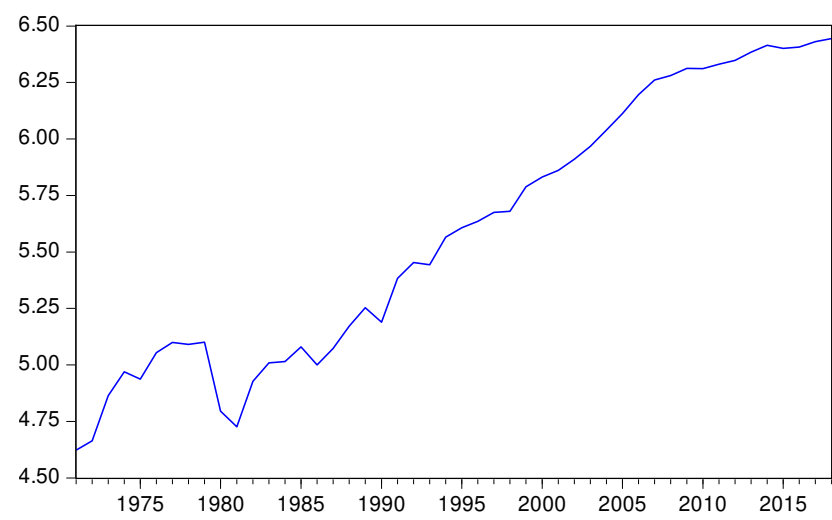




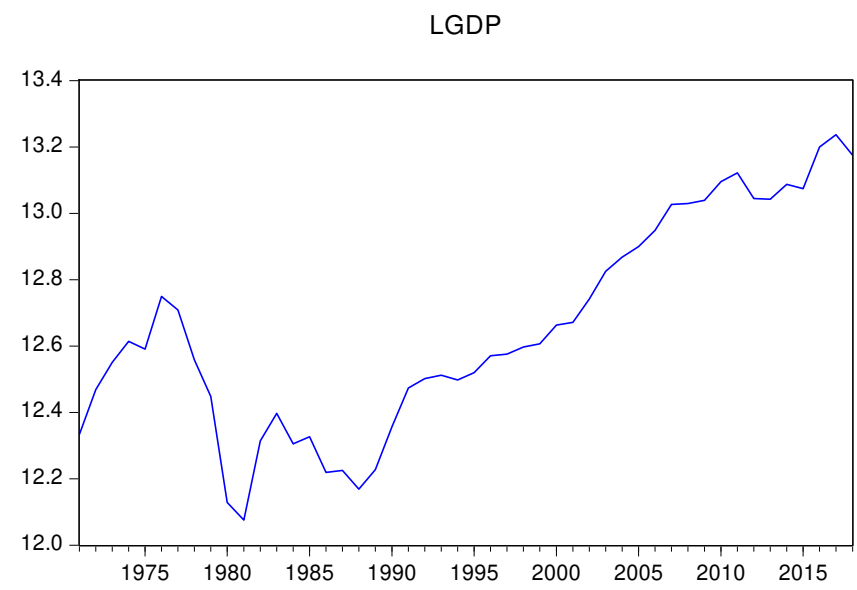

Fig. 4. Trends in $\mathrm{CO}_{2}$ emission, GDP, and WUl from 1971 to 2018.

\section{Methodology and Model Specification}

196

197

Since ARDL is a strong approach for short-run and long-run analysis, it has become a popular and widely used approach, especially for time series analysis (for example, for Irans' economy, Shahpari and Davoudi 2014 and Shahpari et al. 2020 used ARDL). This study uses yearly data for Iran in the 1971-2018 period. In this study, uncertainty index for Iran is obtained from a database of policy uncertainty of WUI based on Ahir at al. (2018). Other data are obtained from database of World Development Indicators (WDI).

Based on Shin et al. (2014) and Hatemi-j (2012), the nonlinear and asymmetric cointegration tests are applied in investigating the cointegration and long-run relationship between the dependent variable $\left(\mathrm{CO}_{2}\right)$ and the explanatory variables (GDP, energy intensity, and economic uncertainty). The nonlinear ARDL is considered in this study because of its advantage over other time series approaches.

The nonlinear ARDL approach of cointegration does not need a particular order of integration for cointegration analysis, and a mixed order of integration I(0) and I(1) could be applied.

This study assesses whether the uncertainty index could affect $\mathrm{CO}_{2}$ emissions. Based on the research variables, the generalized form of the study model can be represented as follows:

$\mathrm{LCO}_{2 \mathrm{t}}=\beta_{0}+\beta_{1} \mathrm{LGDP}_{\mathrm{t}}+\beta_{3} \mathrm{UI}_{\mathrm{t}}+\beta_{2} \mathrm{LEI}_{\mathrm{t}}+\varepsilon_{\mathrm{t}}$

where $\mathrm{LCO}_{2}$, LGDP, UI, and LEI represent the natural logarithm of carbon emission (million-ton carbon equivalent), the natural logarithm of GDP (million \$ US), economic uncertainty index, the natural logarithm of energy intensity, and $\varepsilon$ is the error correction term.

Then, the nonlinear bound test approach is applied to investigate the cointegration relationship. This bound test is developed by Shin et al. (2014) as an extended version of Pesaran et al. (2001). Decomposing selected independent variables can extend the linear version of the Unrestricted Error Correction Model (UECM) into positive and negative shocks (Shin et al. 2014). The ARDL 
$(p, q)$ is converted to the NARDL $(p, q)$ by considering the positive and negative components as follows:

$$
\mathrm{LCO}_{2 \mathrm{t}}=\sum_{\mathrm{j}=1}^{\mathrm{p}} \varphi_{\mathrm{j}} \mathrm{LCO}_{2 \mathrm{t}-\mathrm{j}}+\sum_{\mathrm{j}=0}^{\mathrm{q}}\left(\beta_{1 \mathrm{j}}^{+} \mathrm{LGDP}_{\mathrm{t}-\mathrm{j}}^{+}+\beta_{2 \mathrm{j}}^{-} \mathrm{LGDP}_{\mathrm{t}-\mathrm{j}}^{-}+\beta_{3 \mathrm{j}}^{+} \mathrm{UI}_{\mathrm{t}-\mathrm{j}}^{+}+\beta_{4 \mathrm{j}}^{-} \mathrm{UI}_{\mathrm{t}-\mathrm{j}}^{-}+\beta_{5} \mathrm{LEI}_{\mathrm{t}-\mathrm{j}}\right)+
$$
$\varepsilon_{\mathrm{t}}$

So that $\mathrm{p}$ and $\mathrm{q}$ are the optimal number of lags, $\varphi_{j}$ are the coefficients of the dependent variable lags, $\beta_{i j}$ are the coefficients of the independent variables lags. According to the following relation, the selected independent variables are decomposed into positive and negative components:

$L G D P_{t}^{+}=\sum_{j=1}^{t} \Delta L G D P_{t}^{+}=\sum_{j=1}^{t} \max \left(\Delta L G D P_{t}^{+}, 0\right)$

$L G D P_{t}^{-}=\sum_{j=1}^{t} \Delta L G D P_{t}^{-}=\sum_{j=1}^{t} \min \left(\Delta L G D P_{t}^{-}, 0\right)$

$U I_{t}^{+}=\sum_{j=1}^{t} \Delta U I_{t}^{+}=\sum_{j=1}^{t} \max \left(\Delta U I_{t}^{+}, 0\right)$

$U I_{t}^{-}=\sum_{j=1}^{t} \Delta U I_{t}^{-}=\sum_{j=1}^{t} \min \left(\Delta U I_{t}^{-}, 0\right)$

Where $L G D P_{t}^{+}, U I_{t}^{+}$are partial sum processes of positive changes and $L G D P_{t}^{-}, U I_{t}^{-}$are partial sum processes of negative changes.

The model of $\operatorname{NARDL}(\mathrm{p}, \mathrm{q})$ with the asymmetric error correction is presented as follows:

$$
\begin{aligned}
& \Delta L C O_{2 t}=\gamma_{0}+\gamma_{1} L C O_{2 t-1}+\gamma_{2}^{+} L G D P_{t-1}^{+}+\gamma_{3}^{-} L G D P_{t-1}^{-}+\gamma_{4}^{+} U I_{t-1}^{+}+\gamma_{5}^{-} U I_{t-1}^{-}+\gamma_{6} L E I_{t-1}+ \\
& \sum_{j=0}^{p-1} \alpha_{1 j} \Delta L C O_{2 t-i}+\sum_{j=0}^{q-1} \alpha_{2 j}^{+} \Delta L G D P_{t-i}^{+}+\sum_{j=0}^{q-1} \alpha_{3 j}^{-} \Delta L G D P_{t-i}^{-}+\sum_{j=0}^{q-1} \alpha_{4 j}^{+} \Delta U I_{t-i}^{+}+ \\
& \sum_{j=0}^{q-1} \alpha_{5 j}^{-} \Delta U I_{t-i}^{-}+\sum_{j=0}^{q-1} \alpha_{6} \Delta L E I_{t-i}+\varepsilon_{t}
\end{aligned}
$$

Where $\alpha, \gamma$ represent the short-run and long-run effects of variables. The short-run and longrun analysis investigate the effect of independent variables shock on $\mathrm{CO}_{2}$ emissions and assess the adjustment speed.

The bound-test is done on all the lagged levels of the independent variables. The null hypothesis, no cointegration against the existing cointegration, is investigated by F-statistics. The null hypothesis is rejected where estimated F-statistics are more significant than the upper bound and vice versa (Pesaran et al. 2001). If the values of the F-statistics lie between the upper and lower bounds, no precise decision can be made. Based on the results of the cointegration, the null hypotheses of symmetric coefficients in long-run or short-run can be tested using the Wald statistic following an asymptotic $\chi^{2}$ distribution.

\section{Data and estimation results}

\subsection{Data}

In this study, $\mathrm{CO}_{2}$ emissions is considered as the dependent variable, and the influence of uncertainty index and GDP is investigated. Moreover, energy intensity is considered as a control variable in the model. Likewise, although there are several uncertainty indices, this study uses the 
world uncertainty index. It should be noted that the research variables are transformed into logarithmic forms.

Approaches such as Dickey-Fuller (DF 1979); and Philips-Perron (PP 1990) methods were applied in this study for the test of a unit-root. The unit-root test results are presented in table 2, in which both tests indicate that variables including $\mathrm{LCO}_{2}$ and $\mathrm{LGDP}$ have a unit root in the level form and are stationary in the first-difference form. While UI and LEI variables are stationary in the level form. As stated before, the NARDL approach could be used for variables with mixed order of integration $\mathrm{I}(0)$ and $\mathrm{I}(1)$.

Table 2 Unit root test for variables

\begin{tabular}{|c|c|c|c|c|}
\hline \multicolumn{5}{|c|}{ ADF unit root test } \\
\hline \multirow[t]{2}{*}{ Variable } & \multicolumn{2}{|c|}{ levels } & \multicolumn{2}{|c|}{ First difference } \\
\hline & Without trend & With trend & Without trend & With trend \\
\hline $\mathrm{LCO}_{2}$ & $-0.76(0 / 81)$ & $-2.02(0 / 57)$ & $-5.75(0.00) *$ & $-5.67(0.00) *$ \\
\hline LGDP & $-0.48(0 / 88)$ & $-2.16(0.49)$ & $-4.75(0 / 00) *$ & $-4.85(0.00) *$ \\
\hline UI & $-3.09(0.03) * *$ & $-3.22(0.05)$ & - & - \\
\hline LEI & $-3.53(0.01) *$ & $-4.00(0.01) *$ & - & - \\
\hline \multicolumn{5}{|c|}{ PP Unit Root Test } \\
\hline $\mathrm{LCO}_{2}$ & $-0.76(0 / 81)$ & $-2.13(0.51)$ & $-6.18(0.00) *$ & $-6.13(0.00) *$ \\
\hline LGDP & $-0.50(0 / 88)$ & $-1.78(0.69)$ & $-4.93(0 / 00) *$ & $-4.85(0.00) *$ \\
\hline UI & $-2.98(0.04) * *$ & $-3.18(0.09)$ & - & - \\
\hline LEI & $-5.04(0.00) *$ & $-2.98(0.00) *$ & - & - \\
\hline
\end{tabular}

Notes: $(* *)$ and $(*)$ denote significance at $5 \%$ and $1 \%$ significance level, respectively

Source: Authors estimation

\subsection{Estimation results}

Table 3 shows the results of the asymmetric cointegration test. Based on the bounds test approach, the long-run cointegration is confirmed, as F-statistic is greater than the critical value of the upper bound.

Table 3 Asymmetric Cointegration test results

\begin{tabular}{llc}
\hline F-statistic & \multicolumn{2}{l}{ Critical Value at \%1 Significance Level } \\
\cline { 2 - 3 } $\begin{array}{l}\text { Null Hypothesis: No long-run relationships } \\
\text { exist }\end{array}$ & Bottom Bound & Upper Bound \\
\hline 6.69 & 3.06 & 4.15 \\
\hline
\end{tabular}

Source: Source: Authors estimation

These results established a long-run relationship among the variables. The estimate of the longrun coefficients is reported in table 4. The optimal lag length is selected based on the Akaike Information Criterion (AIC). Furthermore, the error correction form is estimated to distinguish the short-run effects of the descriptive variables from their long-run effects (Table 5).

The long-run and short-run NARDL results show a significant relationship between $\mathrm{CO}_{2}$ emissions and descriptive variables. According to table 4, positive and negative shocks in the partial sum of LGDP increases $\mathrm{CO}_{2}$ emissions, and the relationship is not symmetric. This conclusion is in line 
with theoretical foundations and expected results. According to the previous studies (Lotfalopour et al. 2010; Ghorashi and Alavi Rad 2017; Solaymani 2020), there is a positive relationship between increasing production and $\mathrm{CO}_{2}$ emissions in Iran. The effect of adverse shocks of GDP on carbon emissions in the long-run and short-run is also positive. LGDP has the most significant effect on $\mathrm{CO}_{2}$ emission. Based on the results, a one percent positive shock to LGDP causes a 1.1 percent increase, and a one percent negative shock causes a 0.71 percent increase in $\mathrm{CO}_{2}$ emissions. In justifying this result, it can be mentioned that due to the low energy price and low environmental regulation in Iran, energy is not used optimally and efficiently.

The results of positive and negative shocks of $\mathrm{UI}$ on $\mathrm{CO}_{2}$ emissions show negative relationship. In other words, a positive or negative shock in UI will decrease $\mathrm{CO}_{2}$ emissions. This implies that higher levels of economic policy uncertainties adversely affect $\mathrm{CO}_{2}$ emissions in Iran. This results implying that policy uncertainty may decrease or delay economic production, which in turn will cause a reduction in carbon emissions (Chen et al. 2021). This result, especially for countries that have fossil fuel as a natural resource, is expected. Because usually, in such countries, energy consumption is based on fossil fuel usage. Therefore, when the production decreases, $\mathrm{CO}_{2}$ emission definitely decreases due to the decline in fossil fuel usage.

292 LEI, which is regarded as a control variable in the model, shows a positive relationship with $\mathrm{CO}_{2}$ emissions. So that increasing energy intensity will raise $\mathrm{CO}_{2}$ emissions.

Table 4 long-term coefficient estimates of ARDL model $(2,4,3,4,4,3)$

\begin{tabular}{lll}
\hline Variables & coefficient & t-statistics \\
\hline LGDP $^{+}$ & $1.10^{*}$ & 11.24 \\
LGDP $^{-}$ & $0.71^{*}$ & 4.80 \\
$\mathrm{UI}^{+}$ & $-0.86^{*}$ & -6.09 \\
$\mathrm{UI}^{-}$ & $-.099^{*}$ & -5.86 \\
$\mathrm{LEI}$ & $0.26^{* *}$ & 2.19 \\
$\mathrm{C}$ & $6.90^{*}$ & 6.13 \\
\hline
\end{tabular}

Notes: $(* *)$ and $(*)$ denote significance at $5 \%$ and $1 \%$ significance level, respectively

296 Source: Authors estimation

297 Table 5 short-term coefficient estimates of ARDL model $(2,4,3,4,4,3)$

\begin{tabular}{lllll}
\hline Lag order & 0 & 1 & 2 & 3 \\
\hline$\Delta \mathrm{LCO}_{2}$ & & $-0.74(0.00) *$ & & \\
$\Delta \mathrm{LGDP}^{+}$ & $1.45(0.00) *$ & $-0.08(0.50)$ & $0.40(0.00) *$ & $0.28(0.05) * *$ \\
$\Delta \mathrm{LGDP}^{-}$ & $0.64(0.00) *$ & $0.08(0.61)$ & $0.79(0.00) *$ & \\
$\Delta \mathrm{UI}^{+}$ & $0.32(0.00) *$ & $1.82(0.00) *$ & $1.06(0.00) *$ & $1.71(0.00) *$ \\
$\Delta \mathrm{UI}^{-}$ & $0.00(0.96)$ & $1.05(0.00) *$ & $1.44(0.00) *$ & \\
$\mathrm{LEI}$ & $0.66(0.00) *$ & $0.39(0.00) *$ & $0.38(0.00) *$ & $0.12(0.05) * *$ \\
$\mathrm{ECM}$ & $-0.66(0.00) *$ & $\mathrm{R}^{2}=0.94$ & $\mathrm{AdjR}^{2}=0.90$ & \\
\hline
\end{tabular}

Notes: $(* *)$ and $(*)$ denote significance at $5 \%$ and $1 \%$ significance level, respectively

Source: Authors estimation

300 Finally, the asymmetric impact, in the long run, is examined by the Wald test. The results presented 301 in table 6 show the significance of asymmetry in the long-run parameter of LGDP. Moreover, the 
null hypothesis of a symmetric long-run relationship for UI is not rejected and suggests symmetric effects of UI on carbon emission.

304 Table 6 Long-run asymmetries (WALD test)

\begin{tabular}{lll}
\hline Variables & $x$ 2Chi-Square [Prob] & Asymmetry \\
\hline LGDP & $5.65(0.01)^{*}$ & yes \\
UI & $1.41(0.23)$ & no \\
\hline
\end{tabular}

Notes: $\left.{ }^{*}\right)$ denote significance at $1 \%$ significance level.

306 Source: Authors estimation

307 Table 7 reports the model residual diagnostic tests, including autocorrelation, heteroscedasticity, 308 Ramsey RESET, and normality tests. The results of these residual diagnostic tests indicate that the 309 null hypothesis of autocorrelation, heteroscedasticity, model stability, and normality cannot be 310 rejected. Furthermore, Fig. 5 represents CUSUM and CUSUMSQ tests of the model. The figures 311 show stability in the model, as the significant lines lie between the critical lines.

312 Table 7 Diagnostic Test

\begin{tabular}{ll}
\hline Serial correlation (LM) Test & $2.24(0.11)$ \\
\hline Heteroskedasticity Test (BPG) & $2.54(0.25)$ \\
\hline RESET Test & $0.93(0.34)$ \\
\hline Normality Test & $1.52(0.46)$ \\
\hline
\end{tabular}

Notes: (*) denote significance at $1 \%$ significance level.

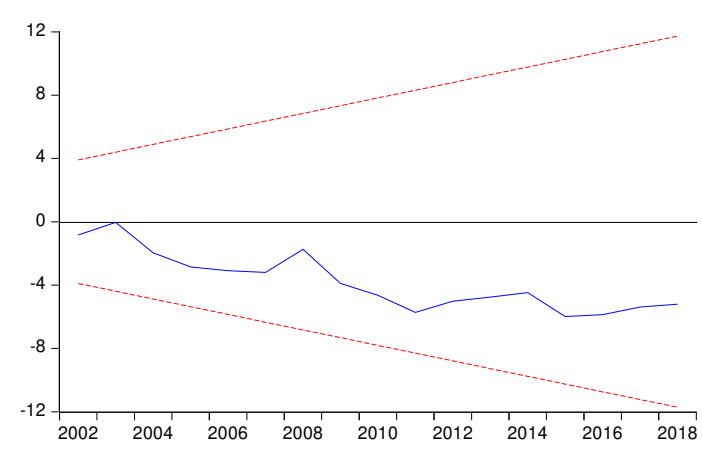

- CUSUM $-5 \%$ Significance

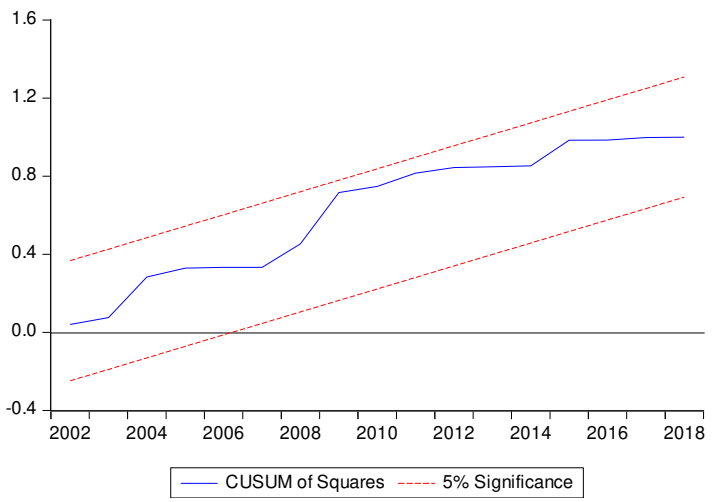

Fig. 5. The CUSUM and CUSUMSQ tests for residuals, obtained by the ARDL approach

Source: Authors estimation

\section{Conclusion and policy implications}

In recent decades, Economic uncertainty has increased rapidly. Economic uncertainty can delay 
Zarifzadeh 2021). In addition to this economic consequences, economic uncertainty can also have environmental impacts (Anser et al. 2021.a;b). For countries such as Iran, which use fossil fuel as their energy resource in the production process, this decreases fossil fuel energy consumption and $\mathrm{CO} 2$ emission.

This study analyzed policy uncertainty and economic growth on carbon dioxide emissions in one of the most carbon dioxide emitter countries, Iran. Applying NARDL approach, the cointegration tests revealed a long-run relationship for all variables. The findings of the study suggest that policy uncertainty and economic growth contribute to $\mathrm{CO}_{2}$ emissions. The negative and positive shocks of LGDP and UI on $\mathrm{CO}_{2}$ emissions in both the short-run and long-run are statistically significant. The coefficients of LGDP indicate a positive effect of economic production on carbon emission in Iran. These findings are consistent with those of Lotfalopour et al. (2010), Ghorashi and Alavi Rad (2017), and Solaymani, 2020 as economic growth is associated with more energy consumption and $\mathrm{CO}_{2}$ emissions. It should be noted that the estimated results indicate an asymmetric effect of economic production on carbon emission in Iran, implying to different responses to the negative and positive shocks.

The results of analyzing asymmetric effects of UI show a symmetric relationship between UI and $\mathrm{CO}_{2}$ emissions. In a manner that a shock in policy uncertainty lowers the carbon emission. Similar to Pirgaip and Dincergok (2020), mitigating $\mathrm{CO}_{2}$ emissions in Iran may occurs at the cost of uncertainty increasing. Meanwhile, Kaveh-Yazdy and Zarifzadeh (2021) also found that EPU can be the reason for higher unemployment rates which is also a signal of decrease in production levels. Ercolani and Natoli (2020) also used economic uncertainty to forecast recession periods, another definition for the decrease in production levels.

Therefore, if policymakers are tend to mitigate environmental pollution and economic uncertainty simultaneously, some complementary policies are needed. In other word, to decouple economic growth from $\mathrm{CO}_{2}$ emissions, it is required to invest in $\mathrm{R} \& \mathrm{D}$, applying low-carbon technologies and energy efficiency targets.

The implication of the relationship between policy uncertainty and $\mathrm{CO}_{2}$ emission is that uncertainty makes it challenging to decide on economic activity, and it cannot be ignored in the GDP- $-\mathrm{CO}_{2}$ emissions relationship. Furthermore, although policy uncertainty will reduce $\mathrm{CO}_{2}$ emissions in Iran, it should be noted that this result may cause locking into the existing fossil-fuelbased economy structure. Therefore, it is reasonable for the countries to promote economic policy that encourages innovation and stimulates capital investment in energy efficiency equipment or appliances. R\&D budget should be raised to find new methods of clean production. Allocating subsidies for clean production methods is another practical policy to reduce fossil fuel consumption and encourage firms to apply modern technologies. Finally, political uproar and unrest should be adequately addressed to reduce its effect on emissions. 


\section{Declarations}

Ethics approval and consent to participate Not applicable

Not applicable

Availability of data and materials All data generated or analyzed during this study are included in the reference list of this article. Data will be available upon request.

Competing interests The authors declare no competing interests.

371

Funding Bozorgmehr University of Qaenat supported the funding of this research, 372 notification number 39215.

373

374

375 Authors' contributions MA analyzed data and developed the model regarding the relationship
between economic uncertainty and $\mathrm{CO} 2$ emissions. GS prepared the historical literature and introduction part of the manuscript. Both authors read and approved the final manuscript.

\section{Acknowledgment}

This article is taken from a research project entitled "Investigation of the asymmetric effect of economic policy uncertainty on pollution emissions using the NARDL approach" approved by the Research Council of Bozorgmehr University of Qaenat, notification number 39215.

The authors would like to thank Bozorgmehr University of Qaenat for the financial support of this research.

\section{References}

Adams S, Adedoyin F, Olaniran E, Bekun FV (2020) Energy consumption, economic policy uncertainty and carbon emissions; causality evidence from resource rich economies. Econ. Analysis Policy 68:179-190

Adedoyin FF, Zakari A (2020) Energy Consumption, Economic Expansion, and CO2 Emission in the UK: The Role of Economic Policy Uncertainty. Science of the Total Environment, https://doi.org/10.1016/j.scitotenv.2020.140014

Ahir H, Bloom N, Furceri D (2018) The World Uncertainty Index. Data access from https`//www.policyuncertainty.com/wui_quarterly.html

Alam MR, Istiak K (2020) Impact of US policy uncertainty on Mexico: Evidence from linear and nonlinear tests. Q. Rev. Econ. Financ. 77:355-366. doi: 10.1016/j.qref.2019.12.002

Al-Thaqeb SA, Algharabali BG (2019) Economic policy uncertainty: A literature review. The Journal of Economic Asymmetries 20, e00133. https://doi.org/10.1016/j.jeca.2019.e00133

Altig D, Baker S, Barrero SM, Bloom N, Bunn P, et al. (2020) Economic uncertainty before and during the COVID-19 pandemic. J. Public Econ. 191:104274 doi: 10.1016/j.jpubeco.2020.104274 
Anser MK, Apergis N, Raza Syed Q (2021.a) Impact of economic policy uncertainty on CO2 emissions: evidence from top ten carbon emitter countries. Environmental Science and Pollution Research https://doi.org/10.1007/s11356-021-12782-4

Anser MK, Syed QR, Lean H H, Alola AA, Ahmad M (2021.b) Do Economic Policy Uncertainty and Geopolitical Risk Lead to Environmental Degradation? Evidence from Emerging Economies.Sustainability 13:5866 https://doi.org/10.3390/su13115866

Anser Mk, Raza Syed Q, Apergis N (2020) Does geopolitical risk escalate CO2 emissions? Evidence from the BRICS countries. Environmental Science and Pollution Research https://doi.org/10.1007/s11356-021-14032-Z

Apergis N, Payne JE (2010) The emissions, energy consumption, and growth nexus: evidence from the commonwealth of independent states. Energy Policy 38(1):650-655

Ashena M, Sadeghi H, Shahpari G (2020). The effects of energy efficiency improvements in the electricity sector on the Iranian economy: A computable general equilibrium approach. Iranian Journal of Economic Studies, 9(1), 7-33 https:// doi. org/ 10. 22099/ ijes. 2020. 35709. 1629

Atsu E, Adams S (2021) Energy consumption, finance, and climate change: Does policy uncertainty matter? Economic Analysis and Policy 70: 490-501

Baker SR, Bloom N, Davis SJ (2016) Measuring economic policy uncertainty. Q. J. Econ., 131(4): 1593-1636 doi: 10.1093/qje/qjw024

Barrero JM, Bloom N, Wright I (2017) Short and long run uncertainty. Washington DC: National Bureau of Economic Research. (No. w23676)

Bloom N (2017) Observations on Uncertainty. Aust. Econ. Rev. 50(1):79-84 doi: 10.1111/1467$\underline{8462.12203}$

Chang Y, He Y, Jin X, Li T, Shih, CM (2020) Media Coverage of Environmental Pollution and the Investment of Polluting Companies. Asia Pac. J. Financ. Stud 49:750-771

Chen Y, Shen X, Wang L (2021) The Heterogeneity Research of the Impact of EPU on Environmental Pollution: Empirical Evidence Based on 15 Countries. Sustainability 13:4166

Dickey DA, Fuller WA (1979) Distribution of the estimators for autoregressive time series with a unit root. Journal of the American Statistical Association 74:427-431

Dinda S (2004) Environmental Kuznets curve hypothesis: a survey. Ecol. Econ. 49:431-455 https://doi.org/10.1016/j.ecolecon.2004.02.011.

Ercolani V, Natoli F (2020) Forecasting US recessions: The role of economic uncertainty. Economics Letters 193: 109302 https://doi.org/10.1016/j.econlet.2020.109302

Ghorashi N, Alavi Rad A (2017) CO2 Emissions, Health Expenditures and Economic Growth in Iran: Application of Dynamic Simultaneous Equation Models. Journal of Community Health Research 6(2):109-116 
Ghosh S (2019) Uncertainty, economic growth its impact on tourism, some country experiences. Asia Pacific J. Tour. Res. 24(1): 83-107. doi: 10.1080/10941665.2018.1542324

Hatemi-J A (2012) Asymmetric causality tests with an application. Empirical Economics 43: 447456

Hosseini SM, Saifoddin A, Shirmohammadi R, Aslani A (2019) Forecasting of CO2 emissions in Iran based on time series and regression analysis. Energy Reports doi: 10.1016/j.egyr.2019.05.004

IPCC. (2013). Summary for policy makers in climate change 2013: The physical science basis contribution of working group 1 to the ffth assessment report of the intergovernmental panel on climate change. Cambridge University Press

Jin X, Wu H (2021) Economic policy uncertainty and cost stickiness. Management Accounting Research 52, 100750

Kaveh-Yazdy F, Zarifzadeh S (2021) Measuring Economic Policy Uncertainty Using an Unsupervised Word Embedding-based Method. Computer Science http://dx.doi.org/10.2139/ssrn.3845847

Kompas T, Pham VH, Tuong NC (2018) The effects of climate change on GDP by country and the global economic gains from complying with the Paris Climate Accord. Earth's Future 6 (8):1153-1173

Lotfalipour MR, Falahi MA, Ashena M (2010) Economic growth, CO2 emissions, and fossil fuels consumption in Iran. Energy 35(12) https://doi.org/10.1016/j.energy.2010.08.004

Nejat P, Jomehzadeh F, Taheri MM, Gohari M, Majid MZA (2015) A global review of energy consumption, $\mathrm{CO}_{2}$ emissions and policy in the residential sector (with an overview of the top ten $\mathrm{CO}_{2}$ emitting countries). Renew Sust Energ Rev 43:843-862

Pata UK (2018) Renewable Energy Consumption, Urbanization, Financial Development, Income and $\mathrm{CO}_{2}$ Emissions in Turkey: Testing EKC Hypothesis with Structural Breaks. Journal of Cleaner Production, 187:770-779 10.1016/j.jclepro.2018.03.236

Perron P (1990) Testing for a unit root in a time series with a changing mean. Journal of Business \& Economic Statistics 8:153-162

Pesaran MH, Shin Y, Smith RJ (2001) Bounds testing approaches to the analysis of level relationships. Journal of Applied Econometrics 16(3):289-326

Pesaran MH, Shin Y, Smith RJ (2001) Bounds Testing Approaches to the Analysis of Level Relationships. J. Appl. Econom. 16, 289-326 https://doi.org/10.1002/jae.616

Pirgaip B, Dinçergök B (2020) Economic policy uncertainty, energy consumption and carbon emissions in G7 countries: evidence from a panel Granger causality analysis. Environmental Science and Pollution Research https://doi.org/10.1007/s11356-020-08642-2 
472

Razmi SF, Ramezanian Bajgiran B, Razmi SMJ, Baensaf Oroumieh K (2020) The Effects of External Uncertainties against Monetary Policy Uncertainty on IRANIAN Stock Return Volatility Using GARCH-MIDAS Approach. International Journal of Energy Economics and Policy 10(4):278-281 https://doi.org/10.32479/ijeep.9176

Reza Syed Q, Bouri E (2021) Impact of economic policy uncertainty on CO2 emissions in the US: Evidence from bootstrap ARDL approach. Journal of Public Affairs e2595 doi:10.1002/pa.2595

Sahinoz S, Erdogan CE (2018) Economic policy uncertainty and economic activity in Turkey. Appl. Econ. Lett. 25:1517-1520

Shafiullah M, Dulal Miah M, Alam MDS, Atif M (2021) Does economic policy uncertainty affect renewable energy consumption? Renewable Energy 179:1500-1521 https://doi.org/10.1016/j.renene.2021.07.092

Shahbaz M, Shafiullah M, khalid U, Song M (2020) A nonparametric analysis of energy environmental Kuznets Curve in Chinese Provinces. Energy Economics 89 doi: 10.1016/j.eneco.2020.104814

Shahpari G, Ashena M, Shahpari M (2020) How Earthquakes can affect Health Sector of the Economy? Disaster Advances 14 (3): 56-62

Shahpari G, Davoudi P (2014) Studying Effects of Human Capital on Income Inequality in Iran. Procedia - Social and Behavioral Sciences 109:1386 - 1389 doi: 10.1016/j.sbspro.2013.12.641

Shahpari G, Sadeghi H, Ashena M, Garcia-Leon D (2021) Drought effects on the Iranian economy: a computable general equilibrium approach. Environment, Development and Sustainability https://doi.org/10.1007/s10668-021-01607-6

Shin Y, Yu B, Greenwood-Nimmo M (2014) Modelling asymmetric cointegration and dynamic multipliers in a nonlinear ARDL framework. In R. C. Sickles, \& W. C. Horrace (Eds.), Festschrift in honor of peter Schmidt, New York, NY: Springer 281-314

Sohail MT, Xiuyuan Y, Usman A, et al. (2021) Renewable energy and non-renewable energy consumption: assessing the asymmetric role of monetary policy uncertainty in energy consumption. Environ Sci Pollut Res 28:31575-31584 https://doi.org/10.1007/s11356-021$\underline{12867-0}$

Solaymani S (2020) A CO 2 emissions assessment of the green economy in Iran. Original Research Article https://doi.org/10.1002/ghg.1969

Stern D (2004) The Rise and Fall of the Environmental Kuznets Curve, World Development 32(8): 1419-1439 https://doi.org/10.1016/j.worlddev.2004.03.004

Wang Q, Xiao K, Lu Z (2020) Does Economic Policy Uncertainty Affect $\mathrm{CO}_{2}$ Emissions? Empirical Evidence from the United States. Sustainability 12,9108 doi:10.3390/su12219108 
502 Wang Q, SunX (2017) Crude oil price: Demand, supply, economic activity, economic policy 503 uncertainty and wars - From the perspective of structural equation modelling (SEM) Energy, $504 \quad$ 133: 483-490 doi: 10.1016/j.energy.2017.05.147

505 World Bank. World Development Indicators Online Database (2020) Available online: $506 \quad$ https://databank. worldbank.org/source/world-developmentindicators

507 Xu H, Zhang C, Li W, Zhang W, Yin H (2018) Economic growth and carbon emission in China: 508 a spatial econometric Kuznets curve? Original scientific paper 36(1):11-28 $509 \quad$ https://doi.org/10.18045/zbefri.2018.1.11

510 Yu J, Shi X, Guo D, Yang L (2020) Economic policy uncertainty (EPU) and firm carbon

511

512 emissions: Evidence using a China provincial EPU index. Energy Economics 94,105071 https://doi.org/10.1016/j.eneco.2020.105071

513

Zakari A, Adedoyin FF, Bekun FV (2021) The effect of energy consumption on the environment in the OECD countries: economic policy uncertainty perspectives. Environ Sci Pollut Res. https://doi.org/10.1007/s11356-021-14463-8

516 